\title{
Using the synthetic form RS5 to obtain new introgressive lines of common wheat
}

\author{
R.O. Davoyan ${ }^{1} \otimes$, I.V. Bebyakina ${ }^{1}$, E.R. Davoyan ${ }^{1}$, Y.S. Zubanova ${ }^{1}$, D.M. Boldakov ${ }^{1}$, D.S. Mikov ${ }^{1}$, V.A. Bibishev ${ }^{1}$, \\ A.N. Zinchenko ${ }^{1}$, E.D. Badaeva ${ }^{2}$ \\ ${ }^{1}$ National Center of Grain named after P.P. Lukyanenko, Krasnodar, Russia \\ ${ }^{2}$ Vavilov Institute of General Genetics of the Russian Academy of Sciences, Moscow, Russia \\ 凶davoyanro@mail.ru
}

\begin{abstract}
The use of the gene pool of wild relatives, which have a significant reserve of genetic diversity, is of immediate interest for breeding common wheat. The creation and use of synthetic forms as "bridges" is an effective method of transferring valuable genetic material from wild relatives to cultivated wheat. For this purpose, genome addition, genome substitution and recombinant "secondary" synthetic forms have been created in the P.P. Lukyanenko National Center of Grain. The synthetic recombination form RS5 (BBAASD ${ }^{t}$ ), in which the third genome consists of chromosomes of Aegilops speltoides $(\mathrm{S})$ and Aegilops tauschii $\left(\mathrm{D}^{\mathrm{t}}\right)$, was obtained from crossing the synthetic forms Avrodes (BBAASS) and M.it./Ae. tauschii $\left(B B A A D^{t} D^{t}\right)$, in which the $D$ genome from Ae. tauschii was added to the BBAA genomes of the durum wheat cultivar Mutico italicum. Introgression lines resistant to leaf rust, yellow rust and powdery mildew have been obtained from backcrosses with the susceptible common wheat cultivars Krasnodarskaya 99, Rostislav and Zhirovka. Twelve resistant lines that additionally have high technological characteristics of grain and flour have been selected. The cytological study (C-banding) has revealed chromosomal modifications in 6 of 8 lines under study. The rearrangements mainly affected the chromosomes of the D genome, 1D, 3D, 4D, 6D and 7D. It was found that in most cases the genetic material from the synthetic form RS5 in the studied lines was represented by substituted chromosomes from Ae. tauschii. In line 5791p17, the substitution of chromosomes $6 \mathrm{D}$ from Ae. tauschii and 7D from Ae. speltoides was revealed. Substitutions 4D $\left(4 D^{t}\right), 6 D\left(6 D^{t}\right)$ from Ae. tauschii and 7D(7S) from Ae. speltoides were obtained for the first time. Molecular analysis of 12 lines did not reveal effective leaf rust resistance genes, presumably present in synthetic forms of M.it./Ae. tauschii and Avrodes. It is assumed that the lines may carry previously unidentified genes for fungal disease resistance, in particular for resistance to leaf rust, from Ae. tauschii and Ae. speltoides.

Key words: common wheat; synthetic forms; disease resistance; protein; gluten; cytological analysis; C-banding; substituted chromosomes; translocations.
\end{abstract}

For citation: Davoyan R.O., Bebyakina I.V., Davoyan E.R., Zubanova Y.S., Boldakov D.M., Mikov D.S., Bibishev V.A., Zinchenko A.N., Badaeva E.D. Using the synthetic form RS5 to obtain new introgressive lines of common wheat. Vavilovskii Zhurnal Genetiki i Selektsii = Vavilov Journal of Genetics and Breeding. 2021;25(7):770-777. DOI 10.18699/VJ21.088

\section{Использование синтетической формы RS5 для получения новых интрогрессивных линий мягкой пшеницы} \author{
А.Н. Зинченко ${ }^{1}$, Е.А. Бадаева ${ }^{2}$ \\ ${ }^{1}$ Национальный центр зерна им. П.П. Лукьяненко, Краснодар, Россия \\ ${ }^{2}$ Институт общей генетики им. Н.И. Вавилова Российской академии наук, Москва, Россия \\ 凶davoyanro@mail.ru
}

Р.О. Аавоян ${ }^{1}$ 을, И.В. Бебякина ${ }^{1}$, Э.Р. Аавоян ${ }^{1}$, Ю.С. Зубанова ${ }^{1}$, А.М. БолАаков ${ }^{1}$, А.С. Миков ${ }^{1}$, В.А. Бибишев ${ }^{1}$,

\begin{abstract}
Аннотация. Актуальной задачей селекции мягкой пшеницы является вовлечение генофонда диких сородичей, обладающих значительным запасом генетического разнообразия. Эффективный метод передачи ценного генетического материала от диких сородичей в культурную пшеницу - создание и использование в качестве «мостиков» синтетических форм. С этой целью в Национальном центре зерна им. П.П. Лукьяненко созданы геномно-замещенные, геномно-добавленные и рекомбинантные «вторичные» синтетические формы. Синтетическая форма RS5 (BBAASD), у которой третий геном состоит из хромосом Aegilops speltoides $(\mathrm{S})$ и Aegilops tauschii $\left(\mathrm{D}^{\mathrm{t}}\right)$, была получена от скрещи-

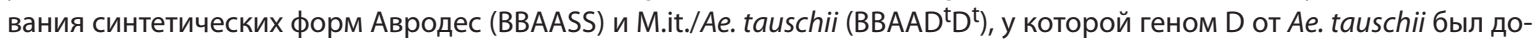
бавлен к геномам BBAA твердой пшеницы Mutico italicum. От беккроссов с восприимчивыми к листовой ржавчине, желтой ржавчине и мучнистой росе сортами мягкой пшеницы Краснодарская 99, Ростислав и Жировка были получены устойчивые к этим болезням интрогрессивные линии. Отобраны 12 линий, которые наряду с устойчивостью к болезням имеют высокие технологические характеристики зерна и муки. Цитологический анализ (C-banding) выявил хромосомные перестройки у шести из восьми исследуемых линий. Перестройки в основном затронули хромосомы
\end{abstract}




\begin{abstract}
генома D - 1D, 3D, 4D, 6D и 7D. Установлено, что генетический материал от синтетической формы RS5 в изученных линиях в большинстве случаев представлен в виде замещенных хромосом от Ae. tauschii. В линии 5791п17 обнаружено замещение хромосом 6D от Ae. tauschii и 7D от Ae. speltoides. Хромосомные замещения 4D $\left(4 \mathrm{D}^{\mathrm{t}}\right), 6 \mathrm{D}\left(6 \mathrm{D}^{\mathrm{t}}\right)$ от Ae. tauschii и 7D(7S) от Ae. speltoides получены впервые. Молекулярный анализ 12 линий не выявил у них эффективных генов устойчивости к листовой ржавчине, предположительно присутствующих в синтетических формах M.it./Ae. tauschii и Авродес. Сделано предположение, что линии могут нести не идентифицированные ранее гены устойчивости $\mathrm{k}$ грибным болезням, в частности к листовой ржавчине, от видов Ae. tauschii и Ae. speltoides.

Ключевые слова: мягкая пшеница; синтетические формы; устойчивость к болезням; белок; клейковина; цитологический анализ; C-banding; замещенные хромосомы; транслокации.
\end{abstract}

\section{Introduction}

Common wheat (Triticum aestivum L.) is one of the main food crops. The constantly growing need to increase its productivity against the background of global climate changes requires further intensification of the breeding process. One of the main conditions for this is the presence of sufficient genetic diversity and, in particular, disease resistance genes. An actual and effective way to expand the genetic diversity of common wheat is to use its numerous related wild and cultivated species as sources of valuable breeding traits (Rasheed et al., 2018). It should be noted that almost all effective diseases resistance genes of common wheat originate from the gene pool of its wild relatives (McIntosh et al., 2015).

One of the most effective methods of transferring valuable genetic material from wild relatives to common wheat is the creation and use of synthetic forms as "bridges". An original approach was developed at the P.P. Lukyanenko National Center of Grain, which made it possible to create genome substituted, genome added and recombinant "secondary" synthetic forms (Zhirov, Ternovskaya, 1984; Davoyan R.O. et al., 2012). The genome substitution form of Avrodes (BBAASS) was used to create recombinant synthetic forms (RS-forms), in which, against the background of BA genomes, the third genome was recombinant and simultaneously consisted of two different wild species genomes (Davoyan E.R. et al., 2012). This form, due to the presence of the $S$ genome from Ae. speltoides, has the ability to promote homoeologous pairing of chromosomes (Tsatsenco et al., 1993), which should have contributed to the production of new translocations and recombinations between chromosomes of different species.

The aim of the study was to use a synthetic form of RS5 $\left(\right.$ BBAASD $^{\mathrm{t}}$ ), in which the third genome consists of Aegilops speltoides (S) and Ae. tauschii $\left(\mathrm{D}^{\mathrm{t}}\right)$ chromosomes, to obtain new introgression lines of common wheat. This paper presents the results of cytological and molecular analysis, evaluation of resistance to fungal diseases, productivity components, technological qualities of grain and flour of common wheat introgression lines obtained using this synthetic form.

\section{Materials and methods}

Introgression lines of common wheat $\left(\mathrm{BC}_{2} \mathrm{~F}_{6}-\mathrm{BC}_{3} \mathrm{~F}_{5}\right)$ obtained with the participation of a synthetic form of RS5 made up the material for this study. Common wheat varieties Krasnodarskaya 99 (lines 4942p17, 5038p17, 5658p19, 5714p18, 5766p19, 5791p17, 5845p18), Rostislav (lines 5001p17, 5656p19) and Zhirovka (lines 5725p18, 5733p19, 5785p18), susceptible to leaf rust, yellow rust and powdery mildew, were used as recipient varieties. The Zhirovka variety has a translocation of 5BS.5BL-5GL, obtained from the species
T. militinae through the synthetic form T. miguschovae. Translocation 1RS.1BL from rye was detected in variety Rostislav.

The study of chromosome pairing in metaphase I of meiosis was carried out in maternal pollen cells on pressed preparations stained with acetic acid hematoxylin according to the generally accepted method (Pausheva, 1974). The number of cells studied in the lines ranged from 169 to 248 .

The assessment of resistance to leaf and yellow rust was carried out at the stage of adult plants in the field, against the background of artificial infection. To assess the resistance to yellow rust, the Gassner and Straib scale was used (Gasner, Straib, 1934). Resistance to leaf rust was determined according to the Mains and Jakson scale (Mains, Jakson, 1926). Plants with reaction type 0 (immune), 1 (highly resistant) and 2 (moderately resistant) were classified as resistant. The resistance of plants with an intermediate type of reaction from 0 to 1 (single very small pustules with necrosis) was indicated by a score of 01 . Plants with reaction type 3-4 were considered susceptible. Resistance to powdery mildew was evaluated on a natural infectious background according to the Geschele scale (Peresipkin, 1979). Plants with a degree of powdery mildew damage of $0-20 \%$ were classified as resistant.

DNA extraction was carried out using the Plaschke et al. method (Plaschke et al., 1995). To identify the $L r$ genes, primers marking the Lr28, Lr35, Lr39 and Lr51 genes were used - CS421570-R, CS421570-L; BCD260F1, 35R2; GDM35-L, GDM35-R; S30-13L, AGA7-759R, respectively (Seyfarth et al., 1999; Singh et al., 2004; Cherukuri et al., 2005; Helguera et al., 2005). The PCR reaction was performed according to the conditions recommended by the authors. Electrophoresis of the PCR fragments was carried out similarly to those previously described (Davoyan E.R. et al., 2018).

Differential staining of chromosomes (C-banding) was performed at the Vavilov Institute of General Genetics according to the method developed by Badaeva and co-authors (Badaeva et al., 1994).

Technological quality of grain and flour was studied at the department of grain technology and biochemistry, P.P. Lukyanenko National Center of Grain, according to the Methods of State Crop Variety Trial (1988). Statistical processing of the obtained results was carried out using the AGROS-2.10 program.

\section{Results}

The synthetic form RS5 showed high resistance to leaf and yellow rust and moderate resistance to powdery mildew, while having very low fertility. To transfer resistance and restore fertility, this form was crossed with susceptible to these diseases common wheat varieties Krasnodarskaya 99, 
Rostislav and Zhirovka. The first generation of hybrid plants was partially fertile and showed resistance to a complex of wheat diseases. Depending on the level of fertility of these plants, backcrossing with common wheat was performed from 1 to 3 times, but in most cases two backcrosses were sufficient to restore it. The plants obtained from backcrosses had from 40 to 42 chromosomes. The results of the cytological study of chromosomal associations in metaphase I of meiosis are shown in Table 1.

In general, the percentage of plants with multivalents did not differ by crossing combinations.

A large number of multivalents $(75 \%)$ was observed in $F_{1}$ plants obtained from crossing the recombinant RS5 form with common wheat, which is explained by the direct influence of the $\mathrm{S}$ genome chromosomes, which are a part of the recombinant sterile form, on the pairing of different genomes chromosomes. Further, along with the increasing number of backcrosses, which were also carried out in order to overcome the low fertility of $\mathrm{F}_{1}$ hybrid plants, the number of plants with multivalents significantly decreases (up to $9 \%$ ). Examples of chromosome pairing in metaphase I of meiosis in hybrid plants are shown in Fig. 1.

The selection of plants for fertility and disease resistance, self-pollination contributed to the meiosis stabilization and necessary signs consolidation. As a result of the plants selection by the chromosomes number close to common wheat (42), 82 lines have now been obtained from the population of hybrid plants obtained on the basis of RS5 synthetics. This article presents the results of studying 12 lines that are closest to the recipient varieties according to the phenotype.

When using the RS5 form, the main purpose was the transmission of common wheat disease resistance. In this regard, an assessment of lines was fulfilled for the most common and harmful diseases - leaf rust (Puccinia triticina Eriks.), yellow rust (Puccinia striiformis f. sp. tritici) and powdery mildew (Blumeria graminis f. sp. tritici). Characterization of introgression lines $\mathrm{RS} 5 \times T$. aestivum for disease resistance for 2019-2021 is given in Table 2.

Eleven lines were resistant to leaf rust. Eight lines showed high resistance with reaction type 01 and $1: 4942 \mathrm{p} 17$, 5656p19, 5733p19, 5766p19, 5714p18, 5725p18, 5785p18 and $5845 \mathrm{p} 18$. The line $5001 \mathrm{p} 17$ was susceptible. The remaining lines had moderate resistance to this disease.

Resistance to yellow rust was carried by all 12 lines, 4 of which, 5656p19, 5725p18, 5791p17 and 5845p18 have the type of reaction to infection 01 and 1 .

Resistance to powdery mildew was shown by 10 lines, with the exception of lines 5038p17 and 5785p18.

Of particular value for breeding are lines that are resistant to a complex of diseases. Three lines, 5001p17, 5038p17 and $5785 \mathrm{p} 18$, had group resistance to two and nine lines to all three diseases. The $5845 \mathrm{p} 18$ line had high resistance to all three diseases. The diversity of disease resistance lines may indicate different introgressions of foreign genetic material into the genome of common wheat.

In order to determine the form of the transferred material from the synthetic RS5 form, the studied lines were crossed with one of the most meiotically stable varieties of common wheat Krasnodarskaya 99 and meiosis was studied in hybrid $\mathrm{F}_{1}$ plants (Table 3).
Table 1. Results of the study of chromosome pairing in metaphase $I$ of meiosis of generation $F_{1}$ and $B C_{1} F_{1}-B C_{3} F_{1}$

\begin{tabular}{llc}
\hline Generation & Total plants studied & $\begin{array}{l}\text { Number of plants } \\
\text { with multivalents }\end{array}$ \\
\hline $\mathrm{F}_{1}$ & 12 & $9(75 \%)$ \\
\hline $\mathrm{BC}_{1} \mathrm{~F}_{1}$ & 31 & $16(52 \%)$ \\
$\mathrm{BC}_{1} \mathrm{~F}_{2}-\mathrm{BC}_{2} \mathrm{~F}_{1}$ & 45 & $12(27 \%)$ \\
\hline $\mathrm{BC}_{2} \mathrm{~F}_{2}-\mathrm{BC}_{3} \mathrm{~F}_{1}$ & 80 & $7(9 \%)$ \\
\hline
\end{tabular}

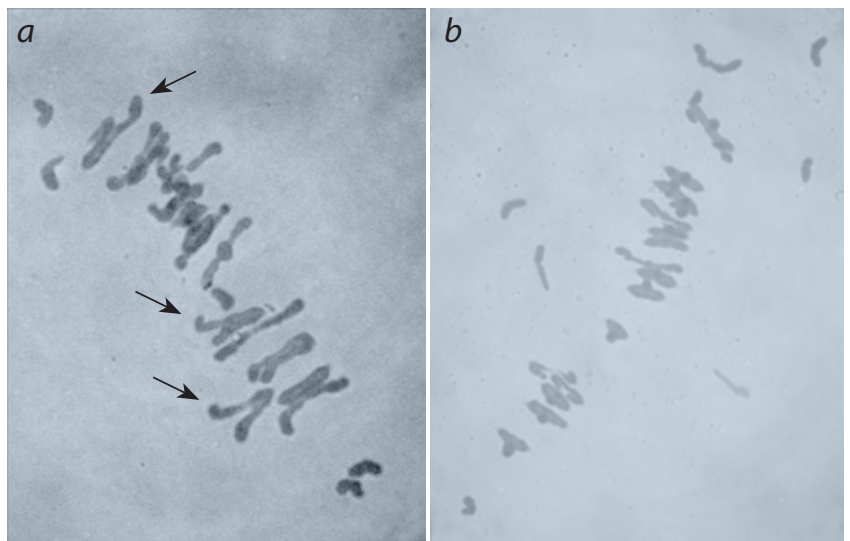

Fig. 1. Chromosome pairing in metaphase I of meiosis in RS5 $\times$ Krasnodarskaya 99 hybrid plants: $a, \mathrm{BC}_{1}\left(14^{\mathrm{II}}+4^{\mathrm{l}}+2^{\mathrm{III}}+1^{\mathrm{IV}}\right) ; b, \mathrm{BC}_{2}\left(19^{\mathrm{II}}+4^{\mathrm{l}}\right)$.

Multivalents are indicated by arrows.

Table 2. Disease resistance

of introgression lines RS5 $\times$ T. aestivum for 2019-2021

\begin{tabular}{|c|c|c|c|}
\hline \multirow{2}{*}{$\begin{array}{l}\text { Line, variety, } \\
\text { synthetic }\end{array}$} & \multicolumn{3}{|l|}{ Resistance } \\
\hline & $\begin{array}{l}\text { to leaf rust } \\
\text { (type of } \\
\text { reaction) }\end{array}$ & $\begin{array}{l}\text { to yellow rust } \\
\text { (type of } \\
\text { reaction) }\end{array}$ & $\begin{array}{l}\text { to powdery } \\
\text { mildew, \% }\end{array}$ \\
\hline $4942 p 17$ & 1 & 2 & 15 \\
\hline $5001 \mathrm{p} 17$ & 3 & 2 & 20 \\
\hline 5038p17 & 2 & 2 & 25 \\
\hline $5656 p 19$ & 01 & 01 & 20 \\
\hline $5658 p 19$ & 2 & 2 & 15 \\
\hline 5733p19 & 1 & 2 & 20 \\
\hline 5766p19 & 1 & 2 & 15 \\
\hline $5714 p 18$ & 01 & 2 & 20 \\
\hline $5725 p 18$ & 1 & 1 & 20 \\
\hline $5785 p 18$ & 1 & 2 & 25 \\
\hline 5791p17 & 2 & 01 & 15 \\
\hline $5845 p 18$ & 01 & 1 & 10 \\
\hline Krasnodarskaya 99 & 4 & 3 & 25 \\
\hline Rostislav & 4 & 4 & 30 \\
\hline Zhirovka & 3 & 3 & 30 \\
\hline RS5 & 01 & 01 & 15 \\
\hline
\end{tabular}


Table 3. Analysis of meiosis in metaphase I in maternal pollen cells $F_{1}$ hybrids obtained from crossing cytologically stable RS $5 \times$ T. aestivum lines with Krasnodarskaya 99

\begin{tabular}{|c|c|c|c|c|c|}
\hline \multirow[t]{2}{*}{ Plant material } & \multirow[t]{2}{*}{ Cells studied } & $21^{11}$ & $20^{11}+2^{1}$ & $19^{\| 1}+4^{l}$ & $\begin{array}{l}\text { Cells with } \\
\text { multivalents }\end{array}$ \\
\hline & & \multicolumn{4}{|l|}{$\%$} \\
\hline 4942 p $17 \times$ K99* & 214 & 77.4 & 16.6 & 4.7 & 1.3 \\
\hline $5001 \mathrm{p} 17 \times \mathrm{K} 99$ & 185 & 80.7 & 10.3 & 6.4 & 2.6 \\
\hline $5038 p 17 \times$ K99 & 190 & 67.4 & 32.6 & - & - \\
\hline $5656 \mathrm{p} 19 \times \mathrm{K} 99$ & 237 & 80.5 & 15.4 & 3.3 & 1.8 \\
\hline $5658 p 19 \times$ K99 & 248 & 65.4 & 30.4 & 4.2 & - \\
\hline $5714 p 18 \times$ K99 & 185 & 48.7 & 38.4 & 10.7 & 2.2 \\
\hline $5725 p 18 \times$ K99 & 210 & 56.2 & 29.5 & 12.4 & 1.9 \\
\hline $5733 p 19 \times$ K99 & 317 & 68.6 & 19.2 & 9.8 & 2.4 \\
\hline 5766 p19×K99 & 262 & 67.2 & 23.7 & 8.4 & 1.7 \\
\hline 5785 p $18 \times$ K99 & 247 & 77.4 & 12.8 & 7.5 & 2.3 \\
\hline $5791 \mathrm{p} 17 \times \mathrm{K} 99$ & 169 & 44.7 & 43.1 & 12.2 & - \\
\hline $5845 p 18 \times$ K99 & 223 & 58.3 & 36.8 & 4.9 & - \\
\hline Krasnodarskaya 99 & 112 & 91.0 & 6.3 & 2.7 & - \\
\hline
\end{tabular}

* Hereinafter: K99 is a variety of wheat Krasnodarskaya 99.

The association of chromosomes of hybrid plants $\mathrm{F}_{1} 20^{\mathrm{II}}+2^{\mathrm{I}}$ and $19^{\mathrm{II}}+4^{\mathrm{I}}$ may indicate the substitution of one or two pairs of wheat chromosomes with foreign ones. Such substitutions can occur in 4 lines out of 12 analyzed - 5038p17, 5658p19, $5791 \mathrm{p} 17$ and $5845 \mathrm{p} 18$. The hybrids of Krasnodarskaya 99 with the other lines have the presence of multivalents, which indicates that they can carry translocations from the RS5 synthetic, Rostislav and Zhirovka varieties. Hybrid plants of the lines 5714p18, 5725p18, 5733p19, 5766p19 along with multivalents form a significant number of cells (about $30 \%$ ) with the association of chromosomes $20^{\mathrm{II}}+2^{\mathrm{I}}$ and $19^{\mathrm{II}}+4^{\mathrm{I}}$. Probably, both translocations and substituted chromosomes may be present in these lines.

To identify the genetic material from the RS5 synthetic and changes in the genome of the obtained lines, the C-banding method was used. Of the eight analyzed lines, six revealed transfer from RS5 synthetics (Table 4).

The rearrangements mainly affected the chromosomes of the D genome. In most cases, the lines carry substituted chromosomes from Ae. tauschii. The most common rearrangements affect chromosomes 1D, 4D and 6D (Fig. 2).

Substitutions $2 \mathrm{~A}\left(2 \mathrm{~A}^{\mathrm{t}}\right)$ and $3 \mathrm{D}\left(3 \mathrm{D}^{t}\right)$ were identified in line $5658 \mathrm{p} 19$. The line $5791 \mathrm{p} 17$ has a $6 \mathrm{D}$ chromosome substitution from Ae. tauschii and 7D from Ae. speltoides. It should be noted that introgression lines with chromosomal substitutions $4 \mathrm{D}\left(4 \mathrm{D}^{\mathrm{t}}\right), 6 \mathrm{D}\left(6 \mathrm{D}^{\mathrm{t}}\right)$ from Ae. tauschii and $7 \mathrm{D}(7 \mathrm{~S})$ from Ae. speltoides were obtained for the first time. Translocation T1BL.1RS from the recipient cultivar Rostislav was revealed in line 5656p19. Translocation T5BL.5GL obtained from the recipient cultivar Zhirovka is present in three lines $-5725 \mathrm{p} 18$, $5733 \mathrm{p} 19$ and $5785 \mathrm{p} 18$. The obtained introgressive lines are
Table 4. Results of the analysis

$\mathrm{RS} 5 \times$ T. aestivum introgression lines by $\mathrm{C}$-banding

\begin{tabular}{|c|c|}
\hline Line & Identified translocations and substitutions \\
\hline $5656 p 19$ & T1BL.1RS \\
\hline $5658 p 19$ & $2 A\left(2 A^{t}\right) ; 3 D\left(3 D^{t}\right)$ \\
\hline $5714 p 18$ & T1BL.1RS; T2AL?; del.3BS; 4D(4Dt) \\
\hline $5725 p 18$ & T1BL.1RS; T5BL.5GL; 4D(4Dt); 6D(6D') \\
\hline 5733p19 & T5BS.5BL-5GL; 1D(1Dt); 6D(6D') \\
\hline $5785 p 18$ & T1BL.1RS; T5BL.5GL \\
\hline $5791 \mathrm{p} 17$ & $6 \mathrm{D}\left(6 \mathrm{D}^{\mathrm{t}}\right) ; 7 \mathrm{D}(7 \mathrm{~S})$ \\
\hline $5845 p 18$ & $1 D\left(1 D^{t}\right) ; 6 D\left(6 D^{t}\right)$ \\
\hline
\end{tabular}

of particular interest as possible new disease resistance genes donors, in particular, to leaf rust, transferred from the species Ae. tauschii and Ae. speltoides. Currently, 5 resistance genes from Ae. tauschii: Lr21, Lr22a, Lr32, Lr39, Lr42 and 6 resistance genes transmitted from Ae. speltoides: Lr28, Lr35, Lr36, Lr47, Lr51, Lr66 (McIntosh et al., 2015) are added to the catalog of wheat gene symbols. DNA markers were used to identify genes for resistance to leaf rust. Earlier (Davoyan E.R. et al., 2012, 2018), we analyzed the synthetic forms Avrodes and M.it./Ae. tauschii for the presence of effective leaf rust resistance genes Lr28, Lr35, Lr47, Lr51 from Ae. speltoides and Lr39 from Ae. tauschii. The resistance gene Lr36 was not 
Line 5714p18

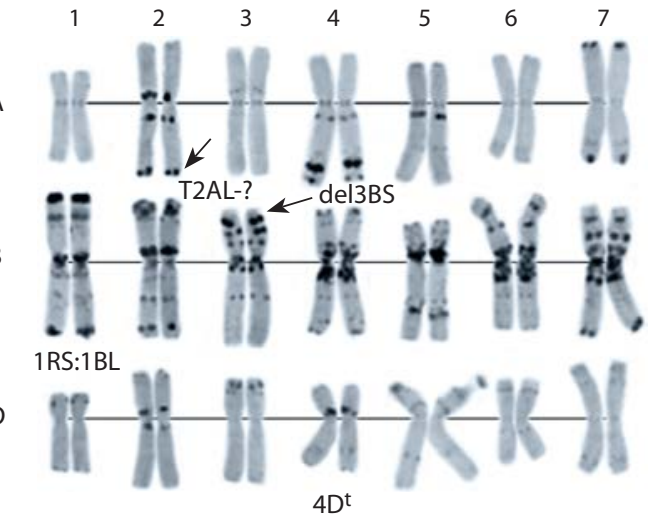

Line $5845 p 18$

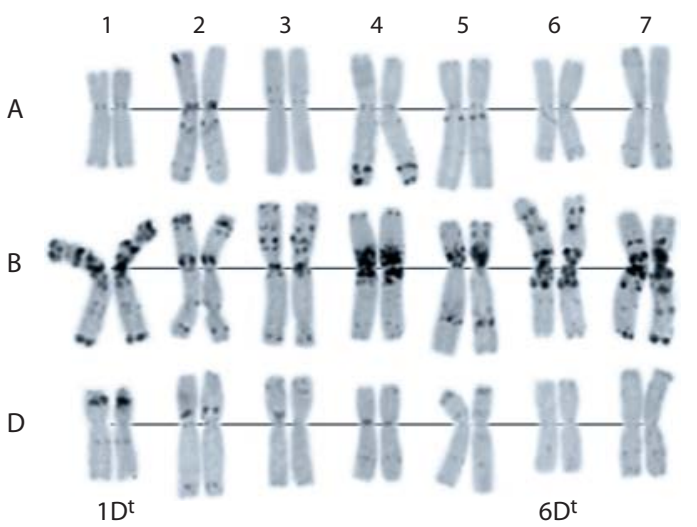

Fig. 2. Karyotypes of introgression lines $5714 \mathrm{p} 18$ and $5845 \mathrm{p} 18$ with genetic material of the recombinant synthetic form RS5.

Table 5. Technological characteristics of grain and flour RS5 $\times$ T. aestivum introgression lines of common wheat

\begin{tabular}{|c|c|c|c|c|c|}
\hline Line & $\begin{array}{l}\text { Protein content, } \\
\%\end{array}$ & $\begin{array}{l}\text { Gluten content, } \\
\%\end{array}$ & $\begin{array}{l}\text { Gluten deformation index, } \\
\text { drop unit }\end{array}$ & $\begin{array}{l}\text { Volume of bread, } \\
\mathrm{ml}\end{array}$ & $\begin{array}{l}\text { Overall baking value, } \\
\text { points }\end{array}$ \\
\hline $5656 p 19$ & 18.6 & 36.8 & 88 & 950 & 4.7 \\
\hline 5658p19 & 15.8 & 29.3 & 82 & 820 & 4.5 \\
\hline $5684 p 18$ & 17.1 & 33.6 & 75 & 850 & 4.5 \\
\hline $5725 p 18$ & 17.9 & 37.0 & 81 & 860 & 4.5 \\
\hline 5733p19 & 16.4 & 31.6 & 68 & 850 & 4.8 \\
\hline $5766 p 19$ & 14.9 & 27.9 & 80 & 860 & 4.7 \\
\hline K99 & 14.4 & 26.0 & 65 & 800 & 4.6 \\
\hline $\mathrm{LSD}_{05}$ & 0.3 & 1.4 & 2 & 19 & - \\
\hline
\end{tabular}

included in the analysis due to the lack of an effective molecular marker for it. Identification of the Lr66 gene was not performed at this stage. It was found that the synthetic form of Avrodes has only Lr28, Lr35 and Lr51 of the listed genes, and the synthetic form M.it/Ae. tauschii has the Lr39 gene. Based on this, the obtained introgressive lines were analyzed only for the presence of effective leaf rust resistance genes Lr28, Lr35, Lr39 and Lr51. The presence of the desired genes has not been established in any of the 12 lines.

To determine the prospects for involving the obtained lines in breeding practice, they were evaluated according to the technological qualities of grain and productivity components. This paper presents the results of six most phenotypically interesting lines evaluation of the 2019 harvest.

One of the most important agronomic traits, especially for lines carrying alien genetic material, is the technological characteristics of grain and flour. Alien introgression can significantly affect the technological qualities of grain and flour. The results of the analysis of lines for some technological parameters are presented in Table 5. The protein and gluten content of the lines largely depend on the conditions of the growing season. All studied lines exceeded the best recipient cultivar
Krasnodarskaya 99 in terms of protein and gluten content. The lines 5656p19 and 5725p18 had the highest levels - 18.6 and $17.9 \%$ protein, 36.8 and $37.0 \%$ gluten, respectively. The protein and gluten content of the Krasnodarskaya 99 variety was 14.4 and $26 \%$ (see Table 5).

Grain technological characteristics are determined by the protein and gluten content, as well as the qualitative indicators of gluten, which, in turn, determine such important characteristics as bread volume, crumb color, bread taste characteristics, etc. As a rule, the lines with alien genetic material have deterioration in the gluten quality. Thus, all the analyzed lines have high levels of gluten deformation index compared to the recipient variety Krasnodarskaya 99. However, the lines 5684p18 and 5733p19 had the gluten quality corresponding to group I according to State Standard, and the lines 5656p19, 5658p19, 5725p18 and 5766p19 had quality group II according to State Standard, which is a good indicator in general for introgressive lines. The volume output of bread in two lines 5658p19 and 5656p19 was 820 and $950 \mathrm{ml}$, respectively, exceeding the volume of bread of the recipient variety Krasnodarskaya $99(800 \mathrm{ml})$. There were significant differences between the lines according to the indicator of the 
Table 6. Yield components of RS $5 \times T$. aestivum introgression lines

\begin{tabular}{|c|c|c|c|}
\hline Line & Weight of 1000 grains, $\mathrm{g}$ & $\begin{array}{l}\text { Number of spikes per } 1 \mathrm{~m}^{2} \text {, } \\
\text { pieces }\end{array}$ & Grain weight per $1 \mathrm{~m}^{2}, \mathrm{~g}$ \\
\hline $5656 p 19$ & 40.3 & 307.7 & 483.5 \\
\hline $5658 p 19$ & 43.2 & 238.7 & 532.7 \\
\hline $5684 p 18$ & 42.3 & 223.5 & 486.5 \\
\hline $5725 p 18$ & 40.7 & 329.2 & 466.0 \\
\hline 5733p19 & 38.0 & 305.8 & 583.5 \\
\hline $5766 p 19$ & 43.9 & 284.3 & 600.3 \\
\hline K99 & 37.4 & 321.7 & 603.7 \\
\hline $\mathrm{LSD}_{0.5}$ & 0.62 & 16.9 & 16.5 \\
\hline
\end{tabular}

general baking assessment. Three lines: 5658p19, 5684p18 and $5725 \mathrm{p} 18$ (4.5 points) were inferior in this indicator to the recipient variety Krasnodarskaya 99 (4.6 points), and two lines, 5656p19 and 5766p19, having a score of 4.7 points, slightly exceeded the indicator of the Krasnodarskaya 99 variety. The line 5733p19 had the best baking rating out of all the lines -4.8 points.

To study productivity, the following characteristics were used: the weight of 1000 grains, the weight of the grain, and the number of spikes per square meter (Table 6). The weight of 1000 grains in the lines varied from 38.0 (5733p19) to $43.9 \mathrm{~g}$ in line 5766p 19, with an average value of the Krasnodarskaya 99 variety -37.4 g. All lines, with the exception of 5733p19, significantly exceed the Krasnodarskaya 99 variety in this sign. Lines 5658p19,5684p 18 and 5766p 19 form a smaller number of spikes per $1 \mathrm{~m}^{2}$. In the other three lines, the differences from the Krasnodarskaya 99 variety were insignificant. The highest yield $\left(600.3 \mathrm{~g} / \mathrm{m}^{2}\right)$, comparable to the Krasnodarskaya 99 variety $\left(603.7 \mathrm{~g} / \mathrm{m}^{2}\right)$, had the line $5766 \mathrm{p} 19$. The other lines were significantly inferior to the Krasnodarskaya 99 variety.

\section{Discussion}

The creation and use of the synthetic form of RS5 was primarily associated with the possibility to transfer new introgressions from Ae. tauschii and Ae. speltoides to common wheat and, as a result, new disease resistance genes. Along with the selection of stable hybrid plants, their cytological study is important. The study of chromosome pairing in metaphase I of meiosis in RS $5 \times$ T. aestivum hybrid plants revealed a relatively large number of plants with multivalents in the early generations of $\mathrm{F}_{1}$ and $\mathrm{BC}_{1} \mathrm{~F}_{1}-75$ and $52 \%$, respectively. Such results are due to the ability of the synthetic form of Avrodes, obtained with the participation of Ae. speltoides, to cause homeologous pairing of chromosomes (Tsatsenco et al., 1993). A significant decrease in the number of plants with multivalents in subsequent generations of $\mathrm{BC}_{2} \mathrm{~F}_{1}-\mathrm{BC}_{3} \mathrm{~F}_{1}$ ( $9 \%$ ) may be associated with the stabilization of the number of chromosomes and their association in meiosis towards common wheat, as well as a decrease in the genetic material Ae. speltoides in them.

The $12 \mathrm{RS} 5 \times \mathrm{T}$. aestivum lines of the $\mathrm{BC}_{2} \mathrm{~F}_{6}-\mathrm{BC}_{3} \mathrm{~F}_{5}$ generation selected for the study differed in resistance to leaf rust, yellow rust and powdery mildew. Lines with the types of reaction to leaf rust 01,1 and 2 , to yellow rust 01,1 and 2 , with a degree of powdery mildew damage of 10,15 and $20 \%$ were identified. The lines differ in their resistance to the complex of these diseases as well. The diversity of disease resistance lines may indicate different transfers of the RS5 genetic material in the genome of common wheat and the possible transfer of a new resistance gene(s).

Cytological analysis (C-banding) revealed chromosomal rearrangements in 6 out of 8 studied lines. The rearrangements mainly affected the chromosomes of the $\mathrm{D}$ genome $1 \mathrm{D}, 3 \mathrm{D}, 4 \mathrm{D}, 6 \mathrm{D}$, and 7D. In most cases, the genetic material from the synthetic RS5 form in the studied lines was found to be presented in the form of substituted chromosomes from Ae. tauschii. In one line - 5791p17 the substitution of chromosomes 6D from Ae. tauschii and 7D from Ae. speltoides was identified. It should be noted that chromosomal substitutions $4 \mathrm{D}\left(4 \mathrm{D}^{t}\right), 6 \mathrm{D}\left(6 \mathrm{D}^{t}\right)$ from Ae. tauschii and $7 \mathrm{D}(7 \mathrm{~S})$ from Ae. speltoides were obtained for the first time. Active participation in rearrangements of chromosomes of the $\mathrm{D}$ genome is explained by the fact that, firstly, Ae. tauschii is a donor of the D genome, secondly, in the synthetic form of Avrodes (BBAASS), the D genome of common wheat is replaced by the $\mathrm{S}$ genome from Ae. speltoides. In line 5656p19, translocation T1BL.1RS from the recipient cultivar Rostislav was revealed. At the same time, in contrast to the Rostislav variety, this line is resistant to leaf rust (01) and yellow rust (01) and has high levels of protein and gluten (18.6 and $35.8 \%$, respectively). Probably, the transfer of genetic material from RS5 of this line occurred through recombination, which is not detected by the C-banding method. The T5BL.5GL translocation obtained from the recipient cultivar Zhirovka was found in three lines $-5725 \mathrm{p} 18,5733 \mathrm{p} 19$, and 5785p18. Currently, this translocation does not provide resistance to leaf rust, yellow rust and powdery mildew.

The genes of resistance to leaf rust $L r 21, L r 22 a, L r 32, L r 39$, Lr42 from the species Ae. tauschii and Lr28, Lr35, Lr36, Lr47, Lr51, Lr66, LrASP5 from Ae. speltoides were transferred to common wheat (Adonina et al., 2012; McIntosh et al., 2015). These genes were transferred from Ae. tauschii to the wheat chromosomes 1D, 2D, 3D, 2D and 1D, respectively; from Ae. speltoides - to 4A, 2B, 6B, 7A, 1B, 3A and 5B, respec- 
tively (Friebe et al., 1996; Helguera al., 2000, 2005; Marais et al., 2010). Despite the rather large number of transferred genes, it is possible that other leaf rust resistance genes may be present in these species, which is also evidenced by the results obtained earlier (Davoyan R.O. et al., 2017).

Based on the marker analysis, it was previously assumed that the synthetic form of M.it/Ae. tauschii has Lr39 of the listed genes, while Avrodes has only three: Lr28, Lr35, and Lr51. The desired genes were not detected in any of the 12 analyzed lines. Probably, these lines may have new leaf rust resistance genes derived from Ae. tauschii and Ae. speltoides.

Genetic material of wild relatives in introgression lines of common wheat, along with positive traits, can also carry undesirable ones, such as lengthening the growing period, deterioration of baking qualities, lodging tendency, decreased yield, etc. (Knott, 1989; Brevis et al., 2008; Timonova et al., 2012; Leonova, Budashkina, 2016).

The study of the 6 most interesting lines by phenotype revealed their diversity in productivity and technological characteristics of grain and flour. The studied lines exceeded the recipient cultivar Krasnodarskaya 99 in protein and gluten content. The lines 5656p19 and 5725p18 had the highest indices -18.6 and $17.9 \%$ protein, 36.8 and $37.0 \%$ gluten, respectively. Despite the fact that all the analyzed lines have high levels of gluten deformation index compared to the Krasnodarskaya 99 variety, they form gluten corresponding to the first and second groups of state standard and have either an equal with Krasnodarskaya 99, or a higher overall baking rating. Thus, along with disease resistance, the studied lines can be used as donors to improve the technological qualities of grain and flour.

All lines, with the exception of 5733p19, significantly exceeded the weight of 1000 grains of the Krasnodarskaya 99 variety. According to the number of spikes per $1 \mathrm{~m}^{2}$, the lines have either equal $(5656 \mathrm{p} 19,5725 \mathrm{p} 18,5733 \mathrm{p} 19)$ or lower indicators $(5658 \mathrm{p} 19,5684 \mathrm{p} 18$ and 5766p19) compared to the Krasnodarskaya 99 variety. With the exception of the 5766p19 line, all the others were significantly inferior to the Krasnodarskaya 99 in terms of grain weight per $1 \mathrm{~m}^{2}$. Based on the obtained data, the reduced productivity of the lines compared to Krasnodarskaya 99 can be tentatively attributed to the fact that against the background of a significantly high protein content (with the exception of the 5766p19 line), which, as a rule, negatively correlates with yield, they form either an equal or significantly smaller number of spikes per $1 \mathrm{~m}^{2}$. It should also be noted that Krasnodarskaya 99 is one of the high-yielding varieties of winter common wheat.

\section{Conclusion}

Thus, the obtained results indicate a wide variety of created introgression lines and the effectiveness of using the synthetic RS5 form for transferring genetic material from Ae. tauschii and Ae. speltoides to common wheat.

\section{References}

Adonina I.G., Petrash N.V., Timonova E.M., Khristov Y.A., Salina E.A. Construction and study of leaf rust resistant common wheat lines with translocations of Aegilops speltoides Tausch. Genetic material. Russ. J. Genet. 2012;48(4):404-409. DOI 10.1134/S10227954120 20020 .
Badaeva E.D., Badaev N.S., Gill B.S., Filatenko A.A. Interspecific karyotype divergence in Triticum araraticum. Plant Syst. Evol. 1994;192(1):117-145. DOI 10.1007/BF00985912.

Brevis J.C., Chicaiza O., Khan I.A., Jackson L., Morris C.F., Dubcovsky J. Agronomic and quality evaluation of common wheat nearisogenic lines carrying the leaf rust resistance gene Lr47. Crop Sci. 2008;48:1441-1451. DOI 10.2135/cropsci2007.09.0537.

Cherukuri D.P., Gupta S.K., Charpe A., Koul S., Prabhu K.V., Singh R.B., Haq Q.M.R. Molecular mapping of Aegilops speltoides derived leaf rust resistance gene Lr28 in wheat. Euphytica. 2005; 143:19-26. DOI 10.1007/s10681-005-1680-6.

Davoyan E.R., Davoyan R.O., Bebyakina I.V., Davoyan O.R., Zubanova Yu.S., Kravchenko A.M., Zinchenko A.N. Identification of a leaf rust-resistance gene in species of Aegilops L., synthetic forms, and introgression lines of common wheat. Russ. J. Genet. Appl. Res. 2012;2(4):325-329. DOI 10.1134/S2079059712040041.

Davoyan E.R., Mikov D.S., Zubanova Y.S., Boldakov D.M., Davoyan R.O., Bebyakina I.V., Bibishev V.A. Study of introgressive lines of common wheat with Aegilops tauschii genetic material for resistance to leaf rust. Vavilovskii Zhurnal Genetiki i Selektsii = Vavilov Journal of Genetics and Breeding. 2018;22(1):97-101. DOI 10.18699/VJ18.336. (in Russian)

Davoyan R.O., Bebyakina I.V., Davoyan E.R., Mikov D.S., Badaeva E.D., Adonina I.G., Salina E.A., Zinchenko A.N., Zubanova Y.S. Use of a synthetic form Avrodes for transfer of leaf rust resistance from Aegilops speltoides to common wheat. Vavilovskii Zhurnal Genetiki i Selektsii = Vavilov Journal of Genetics and Breeding. 2017;21(6):663-670. DOI 10.18699/VJ17.284. (in Russian)

Davoyan R.O., Bebyakina I.V., Davoyan O.R., Zinchenko A.N., Davoyan E.R., Kravchenko A.M., Zubanova Y.S. The use of synthetic forms in preservation and exploitation of the gene pool of wild common wheat relatives. Russ. J. Genet. Appl. Res. 2012;2(6):480-485. DOI 10.1134/S2079059712060044.

Friebe B., Jiang J., Raupp W.J., McIntosh R.A., Gill B.S. Characterization of wheat-alien translocations conferring resistance to diseases and pests: current status. Euphytica. 1996;91:59-87. DOI 10.1007/ BF00035277.

Gasner G., Straib U.W. Weitere Untersuchungen uber die Spezialisierung sverhaltnissedes Gelbrostes Puccinia glumarum (Schm.) Erikss. u. Henn. Arb. Boil. Reichsanstalt. 1934;21:121-145.

Helguera M., Khan I.A., Dubcovsky J. Development of PCR markers for wheat leaf rust resistance gene Lr47. Theor. Appl. Genet. 2000; 100:1137-1143. DOI 10.1007/s001220051397.

Helguera M., Vanzetti L., Soria M., Khan I.A., Kolmer J., Dubcovsky J. PCR markers for Triticum speltoides leaf rust resistance gene Lr51 and their use to develop isogenic hard red spring wheat lines. Crop Sci. 2005;45(2):728-734. DOI 10.2135/cropsci2005.0728.

Knott D.R. The effect of transfers of alien genes for leaf rust resistance on the agronomic and quality characteristics of wheat. Euphytica. 1989;44(1-2):65-72. DOI 10.1007/BF00022601.

Leonova I.N., Budashkina E.B. The study of agronomical traits determining the productivity of the Triticum aestivum/Triticum timopheevii introgression lines with resistance to fungal diseases. Russ. J. Genet. Appl. Res. 2017;7(3):299-307. DOI 10.1134/S207905971 7030091

Mains E.B., Jakson H.S. Physiologic specialization in leaf rust of wheat, Puccinia triticiana Erikss. Phytopatology. 1926;16:89-120.

Marais G.F., Bekker T.A., Eksteen A., Mccallum B., Fetch T., Marais A.S. Attempts to remove gametocidal genes co-transferred to common wheat with rust resistance from Aegilops speltoides. Euphytica. 2010;171(1):71-85. DOI 10.1007/s10681-009-9996-2.

McIntosh R.A., Dubcovsky J., Rogers W.J., Morris C.F., Appels R., Xia X.C. Catalogue of Gene Symbols for Wheat: 2013-2014 Supplement. KOMUGI Integrated Wheat Science Database, 2015. Available at: https://shigen.nig.ac.jp/wheat/komugi/genes/macgene/ supplement2013.pdf 
Methods of State Crop Variety Trial. Moscow, 1988. (in Russian)

Pausheva Z.P. Laboratory Manual on Plant Cytology. Moscow: Kolos Publ., 1974. (in Russian)

Peresipkin V.F. Diseases of Grain Cultures. Moscow: Kolos Publ., 1979;251-260. (in Russian)

Plaschke J., Ganal M.W., Röder M.S. Detection of genetic diversity in closely related bread wheat using microsatellite markers. Theor. Appl. Genet. 1995;91:1001-1007. DOI 10.1007/BF00223912.

Rasheed A., Mujeeb-Kazi A., Ogbonnaya F.C., He Z., Rajaram S. Wheat genetic resources in the post-genomics era: promise and challenges. Ann. Bot. 2018;121:603-616. DOI 10.1093/aob/mcx148.

Seyfarth R., Feuillet C., Schachermayr G., Winzeler M., Keller B. Development of molecular mapping of the adult-plant leaf rust resistance gene Lr35 in wheat. Theor. Appl. Genet. 1999;99:554-560. DOI $10.1007 / \mathrm{s} 001220051268$.
Singh S., Franks C.D., Huang L., Brown-Guedira G.L., Marshall D.S., Gill B.S., Fritz A. Lr41, Lr39 and a leaf rust resistance gene from Aegilops cylindrica may be allelic and are located on wheat chromosome 2DS. Theor. Appl. Genet. 2004;108:586-591. DOI 10.1007/ s00122-003-1477-8.

Timonova E.M., Leonova I.N., Belan I.A., Rosseeva L.P., Salina E.A. The influence of particular chromosome regions of Triticum timopheevii on the formation of resistance to diseases and quantitative traits in common wheat. Russ. J. Genet. Appl. Res. 2012;2(4):330343.

Tsatsenco L.V., Zhirov E.G., Davoyan R.O. Hybrids between wheat and genome-substituted form Avrodes. Cytogenetics and agronomy investigations. Cereal Res. Commun. 1993;21(1):45-50.

Zhirov E.G., Ternovskaya T.K. Genome engineering in wheat. Vestnik Selskokhozyaystvennoy Nauki $=$ Herald of Agricultural Science . 1984;10:58-66. (in Russian)

ORCID ID

R.O. Davoyan orcid.org/0000-0002-6771-5161

Conflict of interest. The authors declare no conflict of interest.

Received August 5, 2021. Revised August 27, 2021. Accepted August 27, 2021. 